\title{
MORE ABOUT ORDOVICIAN MICROFOSSIL DIVERSITY PATTERNS IN THE RAPLA SECTION, NORTHERN ESTONIA
}

\author{
Dimitri KALJO $^{\mathrm{a}}$, Jaak NÕLVAK ${ }^{\mathrm{a}}$, and Anneli UUTELA ${ }^{\mathrm{b}}$
}

\begin{abstract}
${ }^{\mathrm{a}}$ Geoloogia Instituut (Institute of Geology), Estonia pst. 7, EE-0001 Tallinn, Eesti (Estonia)
${ }^{\mathrm{b}}$ Luonontietellinen keskusmuseo, Geologian museo (Geological Museum), PL 11, 00014 Helsingin yliopisto, Suomi ( Finland)
\end{abstract}

Received 27 February 1996, accepted 3 June 1996

\begin{abstract}
Diversity dynamics of acritarchs and chitinozoans was studied in the Rapla borehole section which embraces the Ordovician from the upper Arenig to the topmost Ashgill. The number of taxa per stratigraphic unit, the rate and total rate of appearing and disappearing taxa per unit or per $1 \mathrm{Ma}$, and diversity changes at the unit boundaries were analysed. Both groups demonstrate an energetic radiation-origination period in the Arenig-Llanvirn, a remarkable extinction event in the late Caradoc (top of the Keila Stage), and a mass extinction in the terminal Ordovician (PirguPorkuni stages). Other diversity changes seem to be local and ecologically controlled. The general pattern of microfossil diversity is similar to that established by Sepkoski (Ordovician Odyssey, 1995) for some invertebrates.
\end{abstract}

Key words: Ordovician, acritarchs, chitinozoans, diversity, extinction, radiation.

\section{INTRODUCTION}

In the last decade different events in the Earth's history have aroused wide interest in the world's scientific community. As a result, several IGCP projects have been organized (e.g. 216 "Global Bioevents" and 335 "Biotic recoveries from mass extinctions") to promote detailed study of the most important events, the one occurring at the end of the Ordovician included (Walliser, 1986). In order to understand better the causes and the mechanisms of bioevents, various background studies are needed, especially those describing temporal changes in the taxonomic diversity of different groups of organisms. Diversity dynamics discloses much about evolutionary and environmental biotic changes (radiation, origination, extinction, etc.), provided that adequate methods of description are used. 
The objects of this study were acritarchs and chitinozoans, two groups of organic-walled microfossils of obscure origin. The representatives of the first group have very small (diameter 5-150 $\mu \mathrm{m}$ ), mostly pilose sphaerical vesicles, those of the second group are much larger $(0.5 \mathrm{~mm}$ in size) and of different shape (barrel-, bell-, club-shaped, etc.). Such morphological features obviously affected the floating potential of these organisms as planktic particles and consequently some differences in the distribution of the two groups were anticipated but not unambiguously understood.

The main conclusions of our analysis were presented in short at the International Ordovician Symposium in Las Vegas in 1995 (Kaljo et al., 1995). Here we publish a full account of the results obtained, especially the part of the geological background, sampling and analytical methods allowing better understanding of the discussion.

\section{GEOLOGICAL SETTING}

The data set analysed was derived from a single borehole section at Rapla. Therefore the study area is geographically very limited, but it covers a considerable part of the Ordovician sequence from the upper Arenig to the topmost Ashgill, in terms of the East Baltic stratigraphic classification from the Volkhov to Porkuni stages. Correlation of this classification with British series is given according to Männil (1990).

The Rapla borehole is situated $60 \mathrm{~km}$ south of Tallinn (Fig. 1), within the North Estonian Confacies Belt (Jaanusson, 1976). With regard to the lithological characteristics and subdivision of the section, Põlma (1972) is followed. Only the boundaries of the Uhaku Stage and the lower boundary of the Pirgu Stage have been revised in the light of recent biostratigraphical data (Fig. 2). For the purpose of this study five stages were subdivided into two parts based mainly on the stratigraphic units, currently in use, or lithology, but also for practical reasons. For instance, the Vasavere Formation, which is very thin in the core $(150.5-151.5 \mathrm{~m})$, was included into the Jõhvi Stage, the boundary of the Idavere and Jõhvi stages, however, was drawn tentatively at a depth of $151.5 \mathrm{~m}$ because a few samples were examined from the Vasavere beds (one for acritarchs and three for chitinozoans).

In the section studied 20 working units were distinguished for the analysis of palaeontological data. Their duration was established by the application of the ages of the main Ordovician boundaries defined by Tucker et al. (1990). The stages within a series were tentatively regarded as being of the same duration. Only in some cases the extent of the stages 
was somewhat differentiated according to the completeness and thickness of the unit. In the Caradoc part also some gaps were considered.

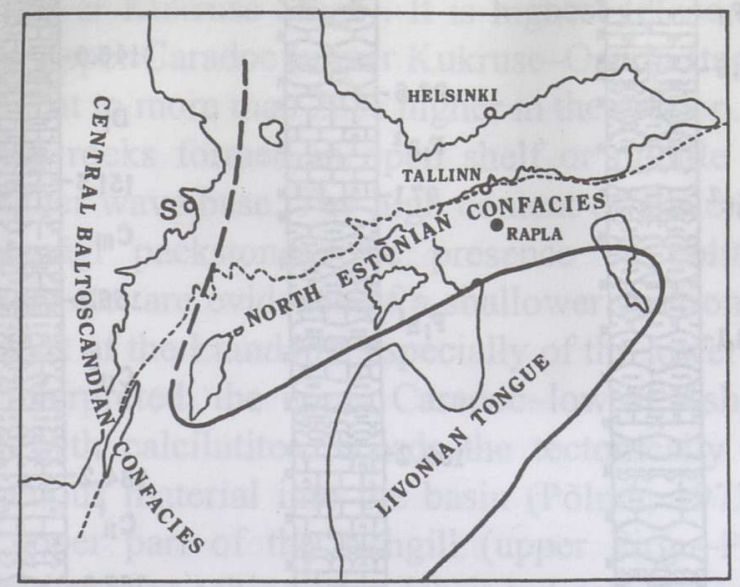

Fig. 1. Location of the Rapla borehole with respect to the Baltic Ordovician confacies belts. S, Stockholm. Thin dashed line-northern limit of the present distribution of the rocks.

A detailed lithological description of the Rapla core section is presented in Fig. 2 compiled according to Põlma (1972). His terminology is given in the legend to the figure. Considering also his data on the content and type of skeletal particles (debris) occurring in the limestone, we can emphasize several more general features and trends in the lithology of the section. For this purpose Dunham's terminology was applied (correlation of both sets of terms was discussed in Nestor, 1990).

In the Arenig and Llanvirn part of the section (Volkhov-Lasnamägi stages) skeletal packstones prevail over wackestones, and oolite intercalations occur. Among skeletal particles trilobites slightly predominate over echinoderms, there is much less brachiopod debris. The Llandeilo and Caradoc (up to the Oandu Stage) are represented by laminar, nodular, and argillaceous wackestones. Trilobites and echinoderms form the bulk of the skeletal debris; in the Idavere-Keila stages also bryozoans are remarkable.

In the upper Caradoc, especially in the Rakvere Stage, calcilutites are most characteristic; skeletal wackestones occur in the lower Nabala Stage. A marked change takes place in the composition of skeletal particles. Algae dominate from the base of the Rakvere Stage to the top of the section. They are less numerous in the Porkuni Stage where echinoderms predominate.

The Ashgill begins with the upper Nabala calcilutites, but higher (Vormsi-Porkuni stages) it is mainly represented by nodular argillaceous 


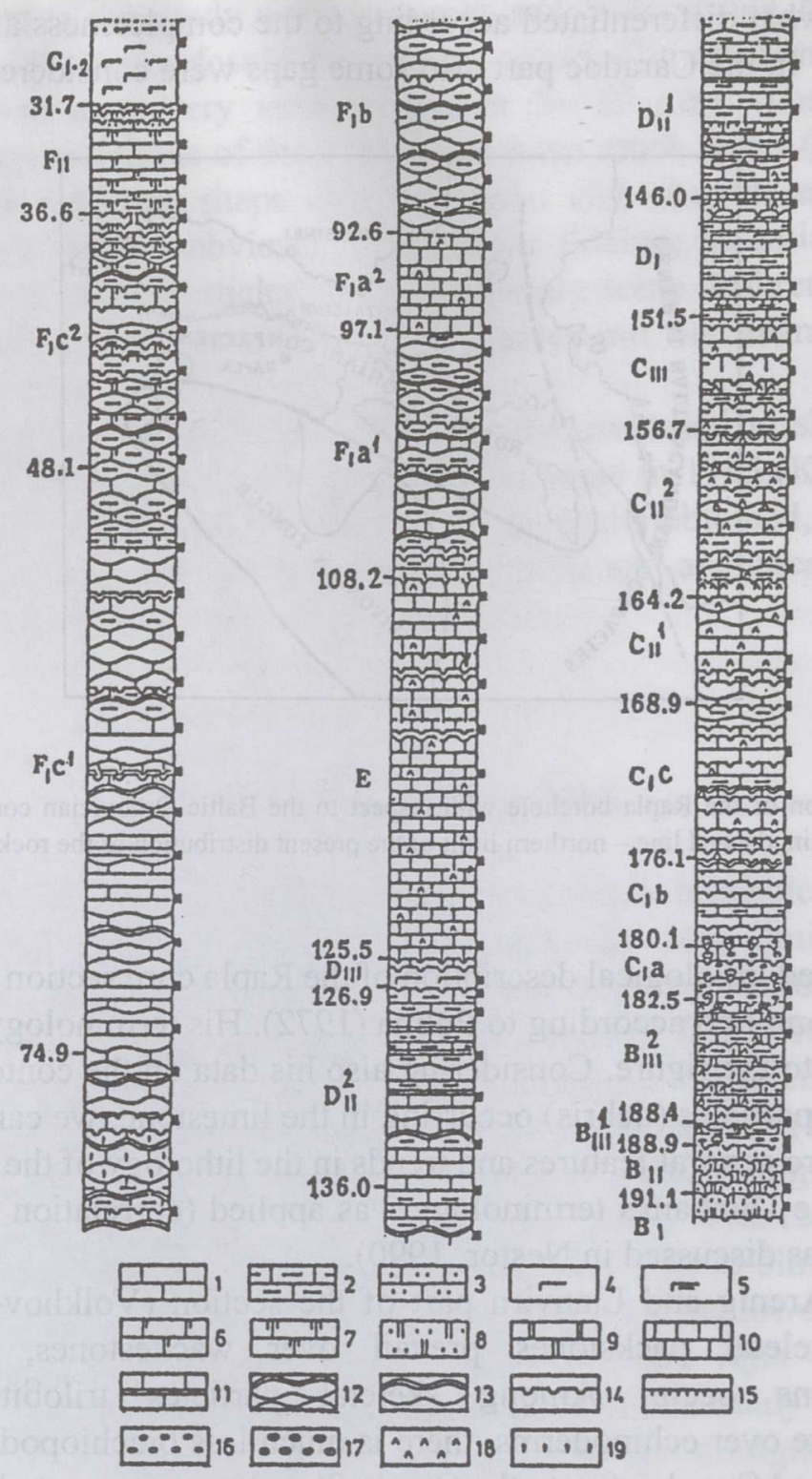

Fig. 2. Lithology and stratigraphy of the Rapla core. Legend: 1, limestone; 2, argillaceous limestone; 3 , silty limestone; 4 , calcareous marl; 5 , argillaceous marl; 6 , limestone with dolomite; 7, dolomitic limestone; 8, dolomitic siltstone; 9, dolomite; 10, cryptocrystalline and microcrystalline limestone; 11 , limestone interbedding with marls; 12 , seminodular limestone interbedding with marls; 13 , nodular limestone interbedding with marls; 14 , discontinuity surfaces; 15 , K-bentonite; 16 , goethite ooids; 17 , calcareous and phosphate ooids; 18 , kukersite (kerogen); 19 , glauconite. Black quadrangles right of the columns denote acritarch sampling places. Units (regional stages, substages): $\mathrm{B}_{\mathrm{I}}$-Latorp; $\mathrm{B}_{\mathrm{II}}-$ Volkhov; $\mathrm{B}_{\mathrm{III}}{ }^{1}, \mathrm{~B}_{\mathrm{III}}{ }^{2}$-lower, upper Kunda; $\mathrm{C}_{\mathrm{I}}{ }^{\mathrm{a}}-$ Aseri; $\mathrm{C}_{\mathrm{I}}$ b-Lasnamägi; $\mathrm{C}_{\mathrm{I}} \mathrm{c}$-Uhaku; $\mathrm{C}_{\mathrm{II}}{ }^{1}, \mathrm{C}_{\mathrm{II}}{ }^{2}$-lower, upper Kukruse; $\mathrm{C}_{\mathrm{III}}$-Idavere; $\mathrm{D}_{\mathrm{I}}$-Jõhvi; $\mathrm{D}_{\mathrm{II}}{ }^{1}$, $\mathrm{D}_{\mathrm{II}}{ }^{2}$-lower, upper Keila; $\mathrm{D}_{\mathrm{III}}$-Oandu; E-Rakvere; $\mathrm{F}_{\mathrm{I}} \mathrm{a}^{1}, \mathrm{~F}_{\mathrm{I}} \mathrm{a}^{2}$-lower, upper Nabala; $\mathrm{F}_{\mathrm{I}} \mathrm{b}-$ Vormsi; $\mathrm{F}_{\mathrm{I}} \mathrm{c}^{1}, \mathrm{~F}_{\mathrm{I}} \mathrm{c}^{2}$-lower, upper Pirgu; $\mathrm{F}_{\mathrm{II}}$-Porkuni; $\mathrm{G}_{1-2}$-Juuru (Silurian). 
wackestones with a few packstone interbeds in the upper part (upper Pirgu and Porkuni stages; Fig. 2).

The clay content is lowest from the base of the section up to the top of the Llandeilo (lower Kukruse Stage). It is highest (close to $25 \%$ ) in the lower and partly upper Caradoc (upper Kukruse-Oandu stages), and varies from a few per cent to more than $25 \%$ higher in the section.

Most of these rocks formed in open shelf or middle ramp settings, below fair-weather wave base. The high content of skeletal debris in the Volkhov-Lasnamägi packstones, the presence of oolites and many hardground levels etc. are evidence of a shallower environment than that of the wackestones of the Llandeilo, especially of the lower Caradoc.

As usually interpreted, the upper Caradoc-lowest Ashgill (RakvereNabala stages) with calcilutites records the tectonically induced weak influx of terrigenous material into the basin (Põlma, 1972; Hints et al., 1989). In the upper part of the Ashgill (upper Pirgu-Porkuni stages) packstones with abundant echinoderm debris indicate a general shallowing of the sea.

The pattern of sedimentary features more or less coincides with the British series and with the subdivided Caradoc. The varying content of terrigenous material suggests a more detailed cyclicity, especially in the upper Caradoc and Ashgill, in general following the stratigraphic units established for the present study. All this forms a changing environmental background for the acritarch and chitinozoan diversity dynamics discussed in this paper. Many discontinuity surfaces (hardgrounds) recorded in the Rapla section (Põlma, 1972) indicate possible serious gaps which should not be forgotten. In the text below, when using wider time units, local rock units considered are added in brackets.

\section{SAMPLING AND ANALYSE METHODS}

The carbonate rocks of the post-Tremadocian Ordovician of the Rapla core (31.7-192.0 m) were sampled for acritarchs (Uutela \& Tynni, 1991; 97 samples, mean weight $50 \mathrm{~g}$ ) and chitinozoans (Nõlvak, unpubl.; 199 samples, mean weight $400 \mathrm{~g}$ ). The samples were mostly taken at regular intervals (0.5-1.0 $\mathrm{m}$ for chitinozoans, $2 \mathrm{~m}$ for acritarchs), but close to stratigraphical boundaries. In the case of thin units the sampling density was somewhat higher.

Acritarchs and chitinozoans are absent in the Latorp and in the lower part of the Volkhov stages due to heavy secondary dolomitization of the Rapla section. In the Porkuni Stage these groups, especially chitinozoans, are absent for the same reason and also because of the occurrence of highenergy sediments or reef facies. These local conditions should be 
considered when evaluating radiation at the very beginning of the section and extinction of Ordovician species at the Pirgu/Porkuni boundary. But in other northern Estonian sections four species of chitinozoans are known from the Porkuni Stage from mudstones of the Siuge Member, three of which have also been recorded from the lowermost Silurian strata. So, if one considers other sections as well, the extinction rate at this level decreases from 100 to $76 \%$. The same is true for acritarchs.

The Rapla core section yields very rich assemblages of acritarchs (319 species, 71 genera) and chitinozoans (110 species). The densely spaced samples and high taxonomic diversity of the assemblages allow the use of this section for examining the diversity patterns and for discussing the possible causes of the microbiotic changes. Most of the numerical data analysed in this paper are presented in three tables.

The identifications on the generic level (Xus sp.) have been left out from the number of species (Tables 1,2). Column 3 shows the number of species recorded in the samples, whereas in column 4 the species are added that were found at higher and lower levels of the section but were missing in samples from an intervening unit under consideration (estimated number of species). The comparison of the data of these two columns (percentage of recorded species of the estimated species, column 5) is an indication of the reliability of the data on observed species.

The data presented in Tables 1,2 show a good correlation between the number of recorded species and the degree of representativeness of these numbers except for the Arenig and Llanvirn acritarch assemblages. In these assemblages the degree of representativeness is $81-89 \%$ though the number of samples per unit is small (1-4). Higher up in the sequence the representativeness of the recorded taxonomic diversity is only $27-35 \%$ for one sample per unit, $48 \%$ for two samples, and $60-69 \%$ for $3-4$ samples. The data are more reliable in units with five samples (over $70 \%$, see Table 1).

It should be kept in mind that a very small number of samples per unit (less than three) reduces the probability of obtaining reliable diversity data. On the other hand, we cannot suggest that the estimated number of species (column 4, Tables 1,2) would be closer to the real diversity state of an assemblage, because most of the species are Lazarus taxa which occur discontinuously (appear-disappear) in a section due to mosaic environmental as well as preservation conditions. The rates of appearing and disappearing species (in per cent, columns 7 and 9) were calculated from the number of taxa recorded from each unit (column 3 ), but only the real first and last records of a species, not intervening occurrences, were considered as appearances and disappearances. 
Table 1

Numerical data for acritarch species and general diversity curves (Figs. 3, 4)

\begin{tabular}{|c|c|c|c|c|c|c|c|c|c|c|c|c|}
\hline \multirow{3}{*}{$\begin{array}{l}\text { Strati- } \\
\text { graphic } \\
\text { unit }\end{array}$} & \multirow{3}{*}{$\begin{array}{l}\text { No. of } \\
\text { sam- } \\
\text { ples }\end{array}$} & \multicolumn{7}{|c|}{ Species } & \multicolumn{3}{|c|}{ Genera } & \multirow{3}{*}{$\begin{array}{c}\text { Changes } \\
\text { at } \\
\text { bound- } \\
\text { aries, \% }\end{array}$} \\
\hline & & \multicolumn{3}{|c|}{ Occurring } & \multicolumn{2}{|c|}{ Appearing } & \multicolumn{2}{|c|}{$\begin{array}{c}\text { Disappear- } \\
\text { ing }\end{array}$} & Occur- & \multicolumn{2}{|c|}{ Appearing } & \\
\hline & & $\begin{array}{c}\text { Recor- } \\
\text { ded } \\
\text { No. }\end{array}$ & $\begin{array}{l}\text { Estim- } \\
\text { ated } \\
\text { No. }\end{array}$ & $\%$ & No. & $\%$ & No. & $\%$ & No. & No. & $\%$ & \\
\hline 1 & 2 & 3 & 4 & 5 & 6 & 7 & 8 & 9 & 10 & 11 & 12 & 13 \\
\hline
\end{tabular}

$\mathrm{G}_{1-2} \quad 2 \quad 29$

$\mathrm{F}_{\mathrm{I}}$

$\begin{array}{lllllllllll}4 & 31 & 47 & 66 & 0 & 0 & 18 & 58 & 12 & 0 & 0\end{array}$

72

$\begin{array}{llllllllllll}\mathrm{F}_{\mathrm{I}} \mathrm{C}^{2} & 7 & 72 & 82 & 88 & 8 & 11 & 44 & 61 & 26 & 0 & 0\end{array}$

$\mathrm{F}_{\mathrm{I}} \mathrm{c}^{1}$ $13 \quad 11$

$\begin{array}{lll}123 & 93 & 13\end{array}$

$\begin{array}{llllll}11 & 46 & 40 & 44 & 6 & 14\end{array}$

$\mathrm{F}_{\mathrm{I}} \mathrm{b}$

$$
9 \quad 98
$$

$122 \quad 80$

342

$122 \quad 34$

$80 \quad 7$

$\mathrm{F}_{\mathrm{I}^{2}}$

$6 \quad 88$

$127 \quad 69$

$\begin{array}{lllll}0 & 0 & 4 & 10 & 33\end{array}$

$\mathrm{F}_{\mathrm{I}} \mathrm{a}^{1}$

$9 \quad 12$

$69 \quad 8$

38

E

$\begin{array}{lllllllllll}1 & 37 & 137 & 27 & 0 & 0 & 6 & 16 & 14 & 0 & 0\end{array}$

$\mathrm{D}_{\text {III }}$

$5 \quad 129 \quad 16$

$\begin{array}{llllll}81 & 19 & 15 & 22 & 17 & 38\end{array}$

$\begin{array}{lll}6 \quad 136 & 157\end{array}$

$87 \quad 22 \quad 16$

$4 \quad 107 \quad 15$

$70 \quad 20$

$\begin{array}{llll}16 & 17 & 13 & 47\end{array}$

$0 \quad 0$

$\mathrm{D}_{\text {II }}$

$\mathrm{D}_{\mathrm{I}}$

$\begin{array}{lll}3 & 79 & 129\end{array}$

$4 \quad 93 \quad 13$

61

$\begin{array}{llll}19 & 8 & 7 & 35\end{array}$

$\mathrm{C}_{\mathrm{II}}$

$129 \quad 6$

$\mathrm{C}_{\mathrm{II}}^{2}$

$135-69-13$

6

$\mathrm{C}_{\mathrm{II}}$

$375 \quad 125$

$125 \quad 60$

$\begin{array}{lllll}3 & 14 & 9 & 10 & 33\end{array}$

24

27

31

$\mathrm{C}^{\mathrm{c}}$

$5101 \quad 140$

$72 \quad 20$

$\begin{array}{llll}3 & 4 & 5 & 24\end{array}$

27

26

$\begin{array}{lllllllllll}2 & 106 & 131 & 81 & 32 & 30 & 12 & 11 & 39 & 11 & 28\end{array}$

$\mathrm{C}_{\mathrm{I}} \mathrm{b}$

$\begin{array}{lll}3 & 86 \quad 97\end{array}$

$4 \quad 75 \quad 86$

$89 \quad 23$

$\begin{array}{llll}27 & 7 & 8 & 29\end{array}$

36

$\mathrm{B}_{\text {III }}$

$\mathrm{B}_{\mathrm{B}}$

$\begin{array}{lllllllllll}1 & 60 & 69 & 87 & 24 & 40 & 3 & 5 & 25 & 9 & 36\end{array}$

44

$\begin{array}{lllllllllll}2 & 51 & (51) & (100) & (51) & (100) & 2 & 4 & 20 & (20) & (100)\end{array}$

Mean:

$85 \quad 116$

$\begin{array}{llll}116 & 73 & 13 & 14\end{array}$

$\begin{array}{llll}14 & 14 & 17 & 31\end{array}$

39

41 
Numerical data for chitinozoan species diversity curves (Figs. 4, 5)

\begin{tabular}{|c|c|c|c|c|c|c|c|c|c|}
\hline \multirow{3}{*}{$\begin{array}{l}\text { Strati- } \\
\text { graphic } \\
\text { unit }\end{array}$} & \multirow{3}{*}{$\begin{array}{c}\text { No. of } \\
\text { samples }\end{array}$} & \multicolumn{7}{|c|}{ Species } & \multirow{3}{*}{$\begin{array}{c}\text { Changes } \\
\text { at } \\
\text { bound- } \\
\text { aries, \% }\end{array}$} \\
\hline & & \multicolumn{3}{|c|}{ Occurring } & \multicolumn{2}{|c|}{ Appearing } & \multicolumn{2}{|c|}{ Disappearing } & \\
\hline & & $\begin{array}{l}\text { Recor- } \\
\text { ded No. }\end{array}$ & $\begin{array}{l}\text { Estim- } \\
\text { ated No. }\end{array}$ & $\%$ & No. & $\%$ & No. & $\%$ & \\
\hline 1 & 2 & 3 & 4 & 5 & 6 & 7 & 8 & 9 & 10 \\
\hline $\mathrm{F}_{\mathrm{II}}$ & 5 & 0 & 0 & 0 & 0 & 0 & 0 & 0 & \\
\hline $\mathrm{F}_{\mathrm{I}} \mathrm{c}^{2}$ & 19 & 17 & 17 & 100 & 6 & 35 & 17 & 100 & \\
\hline $\mathrm{F}_{\mathrm{I}} \mathrm{c}^{1}$ & 25 & 17 & 20 & 85 & 2 & 12 & 9 & 53 & \\
\hline $\mathrm{F}_{\mathrm{I}} \mathrm{b}$ & 12 & 24 & 25 & 96 & 6 & 25 & 8 & 33 & 56 \\
\hline $\mathrm{F}_{\mathrm{I}^{2}} \mathrm{a}^{2}$ & 6 & 15 & 22 & 68 & 2 & 13 & 3 & 20 & 40 \\
\hline $\mathrm{F}_{\mathrm{I}^{2}}{ }^{1}$ & 14 & 21 & 25 & 84 & 9 & 43 & 6 & 29 & 48 \\
\hline E & 16 & 16 & 21 & 76 & 5 & 31 & 2 & 13 & 44 \\
\hline $\mathrm{D}_{\text {III }}$ & 3 & 9 & 16 & 56 & 4 & 44 & 0 & 0 & 71 \\
\hline $\mathrm{D}_{\mathrm{II}}^{2}$ & 7 & 13 & 20 & 65 & 1 & 8 & 8 & 62 & 44 \\
\hline $\mathrm{D}_{\mathrm{II}}^{1}$ & 7 & 15 & 24 & 63 & 2 & 13 & 5 & 33 & 32 \\
\hline $\mathrm{D}_{\mathrm{I}}$ & 8 & 17 & 25 & 68 & 3 & 18 & 2 & 12 & 44 \\
\hline $\mathrm{C}_{\text {III }}$ & 12 & 26 & 29 & 90 & 7 & 27 & 7 & 27 & 41 \\
\hline $\mathrm{C}_{\mathrm{II}}^{2}$ & 9 & 26 & 28 & 93 & 6 & 23 & 6 & 23 & 40 \\
\hline $\mathrm{C}_{\mathrm{II}}^{1}$ & 7 & 28 & 29 & 97 & 6 & 21 & 7 & 25 & 27 \\
\hline $\mathrm{C}_{\mathrm{I}} \mathrm{c}$ & 11 & 24 & 29 & 83 & 3 & 13 & 2 & 8 & 30 \\
\hline $\mathrm{C}_{\mathrm{I}} \mathrm{b}$ & 9 & 27 & 29 & 93 & 7 & 26 & 6 & 22 & 40 \\
\hline $\mathrm{C}_{\mathrm{I}} \mathrm{a}$ & 6 & 27 & 28 & 96 & 10 & 37 & 6 & 22 & 50 \\
\hline $\mathrm{B}_{\mathrm{III}}^{2}$ & 8 & 25 & 25 & 100 & 14 & 56 & 7 & 28 & 61 \\
\hline $\mathrm{B}_{\mathrm{III}}^{1}$ & 2 & 14 & 14 & 100 & 9 & 64 & 3 & 21 & 72 \\
\hline $\mathrm{B}_{\mathrm{II}}$ & 6 & 9 & 9 & 100 & 9 & 100 & 4 & 44 & \\
\hline & Mean: & 19 & 23 & 80 & 6 & 32 & 6 & 30 & 50 \\
\hline
\end{tabular}


In order to examine the relationship in the diversity curves (Figs. 3, 5) between the duration of each stratigraphic unit and the number of species (or genera) in these units, the data were analysed (Table 3, Fig. 4) by applying the total rate and per taxon rate concepts of Johnson \& Kauffman (1990). Because the plots of the total rate and per taxon rate curves agree fairly closely, only the first one is presented.

Table 3

Appearance and disappearance rates of acritarch and chitinozoan taxa in the Rapla section

\begin{tabular}{|c|c|c|c|c|c|c|c|c|c|c|c|}
\hline \multirow{4}{*}{$\begin{array}{c}\text { Strati- } \\
\text { graphic } \\
\text { unit }\end{array}$} & \multirow{4}{*}{$\begin{array}{c}\text { Dura- } \\
\text { tion } \\
\text { Ma }\end{array}$} & \multicolumn{6}{|c|}{ Acritarchs } & \multicolumn{4}{|c|}{ Chitinozoans } \\
\hline & & \multicolumn{4}{|c|}{ Appearance rate } & \multicolumn{2}{|c|}{$\begin{array}{c}\text { Disappearance } \\
\text { rate }\end{array}$} & \multicolumn{2}{|c|}{$\begin{array}{l}\text { Appearance } \\
\text { rate }\end{array}$} & \multicolumn{2}{|c|}{$\begin{array}{l}\text { Disappear- } \\
\text { ance rate }\end{array}$} \\
\hline & & \multicolumn{2}{|c|}{ Total } & \multicolumn{2}{|c|}{ Per taxon } & Total & $\begin{array}{c}\text { Per } \\
\text { taxon }\end{array}$ & Total & $\begin{array}{l}\text { Per } \\
\text { taxon }\end{array}$ & Total & $\begin{array}{c}\text { Per } \\
\text { taxon }\end{array}$ \\
\hline & & spp. & gen. & spp. & gen. & spp. & spp. & spp. & pp. & spp. & p. \\
\hline II & 1.6 & 0 & 0 & 0 & 0 & 11.3 & 36 & 0 & 0 & 0 & 0 \\
\hline $\mathrm{F}_{\mathrm{I}} \mathrm{c}^{2}$ & 1.8 & 4.4 & 0 & 0.06 & 0 & 24.4 & 0.34 & 3.3 & 0.20 & 9.4 & 0.60 \\
\hline $\mathrm{F}_{\mathrm{I}} \mathrm{c}^{1}$ & 1.7 & 7.6 & 3.5 & 0.07 & 0.08 & 27.1 & 0.24 & 1.2 & 0.07 & 5.3 & 0.31 \\
\hline $\mathrm{F}_{\mathrm{I}} \mathrm{b}$ & 1.6 & 4.4 & 0.6 & 0.04 & 0.02 & 7.5 & 0.08 & 3.8 & 0.16 & 5.0 & 0.21 \\
\hline $\mathrm{F}_{\mathrm{I}} \mathrm{a}^{2}$ & 1.3 & 0 & 0 & 0 & 0 & 31 & 0.07 & 1.5 & 10 & 2.3 & .15 \\
\hline $\mathrm{F}_{\mathrm{I}^{2}} \mathrm{a}^{1}$ & 1.4 & 5.7 & 1.4 & 0.06 & 0.04 & 10.0 & 0.11 & 6.4 & 0.31 & 4.3 & 0.20 \\
\hline F & 1.3 & 10.0 & 1.5 & 008 & 0.04 & 13.1 & 0.11 & 3.8 & 0.24 & 1.5 & 0.10 \\
\hline $\mathrm{D}_{\text {III }}$ & 1.3 & 0 & 0 & 0 & 0 & 4.6 & 12 & 3.1 & 4 & 0 & 0 \\
\hline $\mathrm{D}_{\mathrm{II}}^{2}$ & 1.3 & 14. 6 & 0 & 0.11 & 0 & 16.9 & 0.13 & 0.8 & 0.06 & 6.2 & 0.47 \\
\hline $\mathrm{D}_{\mathrm{II}}^{1}$ & 1.3 & 16. 7 & 1.5 & 0.12 & 0.03 & 13.1 & 0.10 & 1.5 & 0.10 & 3.8 & 0.26 \\
\hline $\mathrm{D}_{\mathrm{I}}$ & 1.2 & 16. 7 & 0.8 & 0.16 & 0.02 & 0.1 & 0.06 & 2.5 & .15 & 1.7 & 0.10 \\
\hline $\mathrm{C}_{\mathrm{III}}$ & 1.3 & 4.6 & 1.5 & 0.06 & 0.05 & 5.4 & 0.07 & 5.4 & 0.21 & 5.4 & 0.21 \\
\hline $\mathrm{C}_{\mathrm{II}}^{2}$ & 1.6 & 8.1 & 0 & 0.09 & 0 & 5.6 & 0.06 & 3.8 & 0.14 & 3.8 & 0.14 \\
\hline $\mathrm{C}_{\mathrm{II}}^{1}$ & 1.2 & 1.7 & 0.8 & 0.02 & 0.03 & 3.3 & 0.04 & 5.0 & 0.18 & 5.8 & 0.21 \\
\hline $\mathrm{C}_{\mathrm{I}} \mathrm{c}$ & 1.8 & 11. 1 & 2.2 & 0.11 & 0.06 & 8.3 & 0.08 & 1.8 & 07 & 1.1 & 0.05 \\
\hline $\mathrm{C}_{\mathrm{I}} \mathrm{b}$ & 1.5 & 21.3 & 7.3 & 0.20 & 0.19 & 8.0 & 0.08 & 4.7 & 0.17 & 4.0 & 0.15 \\
\hline $\mathrm{C}_{\mathrm{I}^{\mathrm{a}}}$ & 1.5 & 15.3 & 3.3 & 0.18 & 0.11 & 4.7 & 0.05 & 6.7 & 0.25 & 4.0 & 0.15 \\
\hline $\mathrm{B}_{\mathrm{III}}^{2}$ & 1.8 & 10.0 & 2.8 & 0.13 & 0.10 & 3.3 & 0.04 & 7.8 & 0.31 & 3.9 & 0.16 \\
\hline $\mathrm{B}_{\mathrm{III}}{ }^{1}$ & 1.2 & 20.0 & 7.5 & 0.33 & 0.30 & 2.5 & 04 & 7.5 & 0.54 & 2.5 & 0.18 \\
\hline $\mathrm{B}_{\text {II }}$ & 2.0 & 25.5 & 10.0 & 0.50 & 0.50 & 1.0 & 0.04 & 4.5 & 0.50 & 2.0 & 0.22 \\
\hline $\mathrm{Me}$ & & 9.9 & 2.2 & 0.12 & 0.08 & 9.0 & 0.11 & 3.8 & 0.18 & 3.6 & 0.19 \\
\hline
\end{tabular}

Total rate $=$ No. of appearing (or disappearing) taxa per $1 \mathrm{Ma}$. Per taxon rate $=$ total rate per taxon recorded from a stratigraphic unit. 


\section{ACRITARCHS}

In the Rapla section the acritarch flora is rich and diverse practically throughout the Ordovician. Each stratigraphic unit is characterized on average by 85 species belonging to 31 genera. Only some minimum levels, for instance the Oandu or Porkuni stages, are nearly 2.5 times less diverse. The maximum diversity in the Keila Stage differs from the average only 1.5 times.

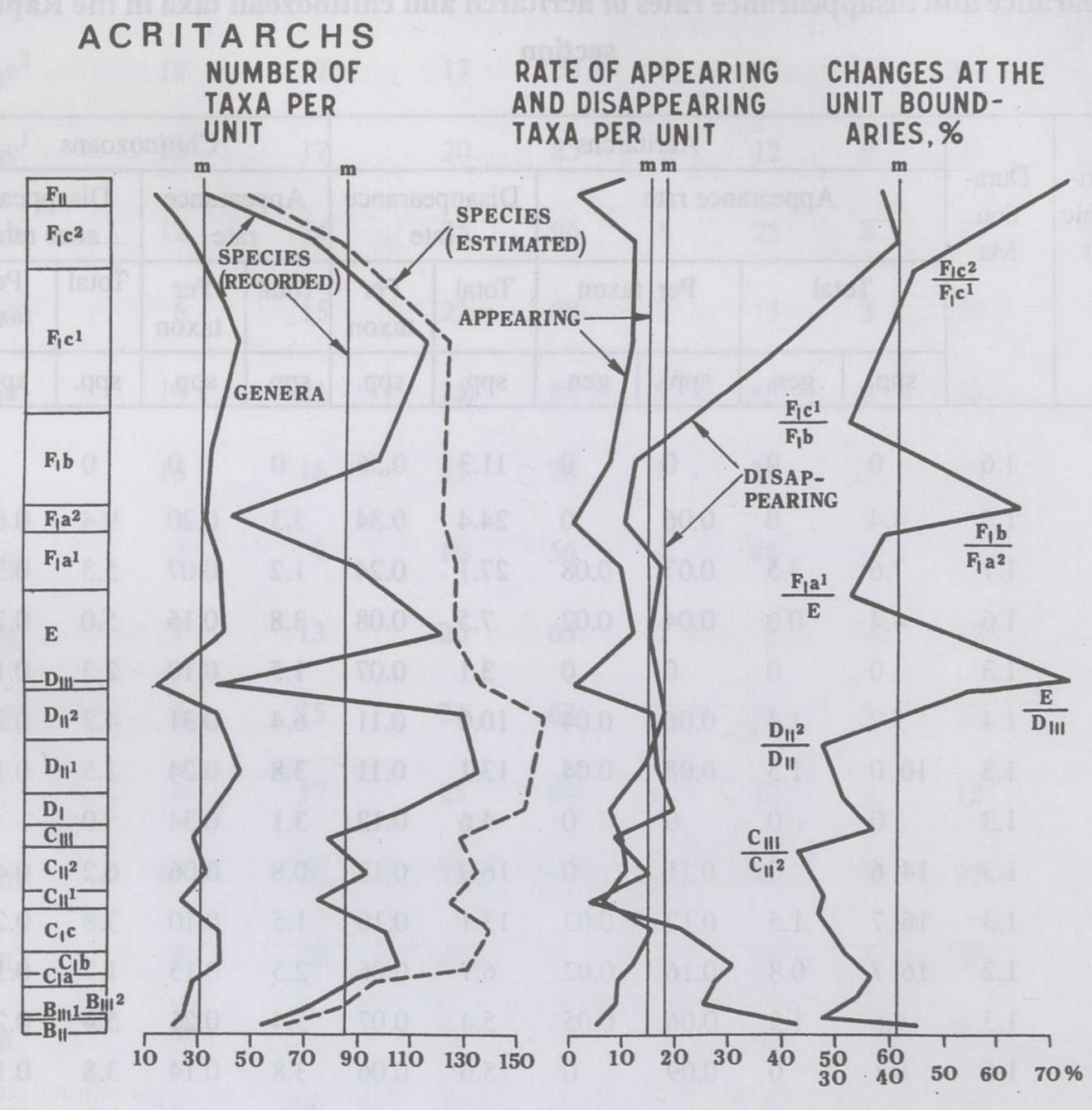

Fig. 3. Acritarch diversity. Stratigraphical column according to thickness. Unit symbols see Fig. 2. $\mathrm{m}$, mean value level. Numerical data in Table 1.

In the Arenig and Llanvirn (the percentage of appearing species is 25$40 \%$, that of new genera is $17-36 \%$ ) the appearance of new taxa is fairly rapid (Table 1, Figs. 3, 4). Origination intensity decreases in the early Caradoc, falling below the mean level (14\%) and, except for the JõhviKeila stages, it is constantly low up to the late Ordovician. The total rate of appearance (Fig. 4) has additional peaks in the curve, but shows the same regularity. An increase in the origination intensity in the Ashgill (early 
Pirgu time) is notable with respect to the total appearance rate of the genera exceeding the mean level (Fig. 4). This seems to be connected with the appearance of several new genera (Estiastra, Pulvinosphaeridium, Schismatosphaeridium, etc.) which are more widely distributed in the Silurian.

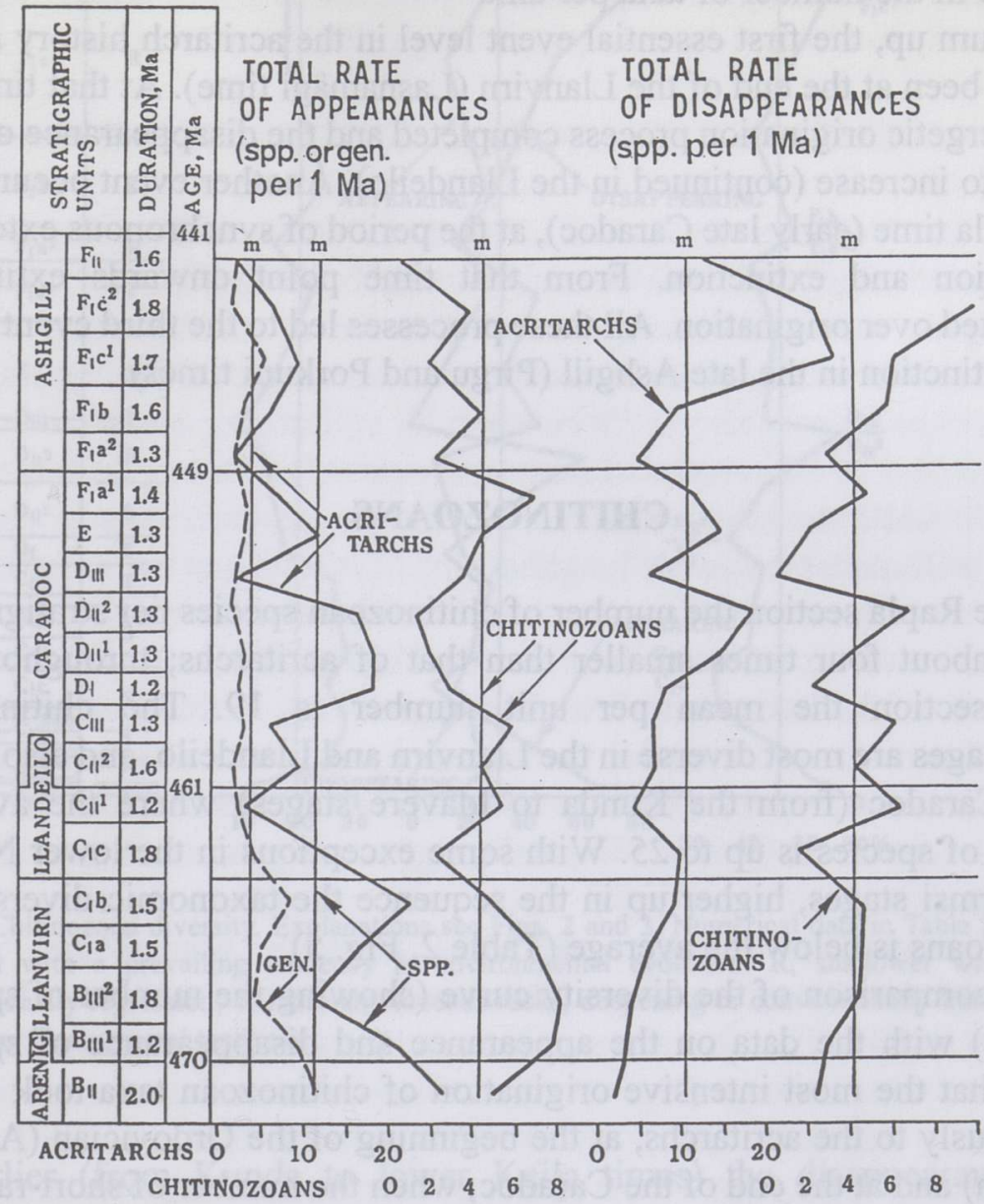

Fig. 4. Total appearance and disappearance rates of acritarchs and chitinozoans. Explanation of unit symbols see Fig. 2. Database in Table 3. Stratigraphical column according to the geochronometric time scale by Tucker et al., 1990.

An opposite tendency can be observed in the change of the disappearance intensity of taxa (Table 1, Fig. 3). The initially very slow process reaches the first low peak (but still below the mean level for the whole Ordovician) in the Llandeilo (Uhaku time); in the late Caradoc (beginning from Keila time) the disappearance intensity reaches almost the average level (17\%). In the Ashgill (Pirgu and Porkuni times) it rises to the value of $40=61 \%$ (Table 1) and this is close to what can be termed as mass extinction. The process is also seen in Fig. 3 which shows a rapid 
decrease in the number of taxa. The total disappearance rate curve (Fig. 4) reveals the same tendencies with distinct peaks in Keila and Pirgu times. In Keila time the per taxon rate of disappearances rises abruptly and is there twice as high as in lower units (Table 3). This shows that the intensive extinction which started in the late Caradoc is not related to an increase in the number of taxa per unit.

To sum up, the first essential event level in the acritarch history seems to have been at the end of the Llanvirn (Lasnamägi time). At that time the first energetic origination process completed and the disappearance of taxa started to increase (continued in the Llandeilo). Another event occurred in late Keila time (early late Caradoc), at the period of synchronous extensive origination and extinction. From that time point onwards extinction dominated over origination. All these processes led to the third event level: mass extinction in the late Ashgill (Pirgu and Porkuni times).

\section{CHITINOZOANS}

In the Rapla section the number of chitinozoan species per stratigraphic unit is about four times smaller than that of acritarchs; throughout the whole section the mean per unit number is 19. The chitinozoan assemblages are most diverse in the Llanvirn and Llandeilo, and also in the lower Caradoc (from the Kunda to Idavere stages) where the average number of species is up to 25. With some exceptions in the lower Nabala and Vormsi stages, higher up in the sequence the taxonomic diversity of chitinozoans is below the average (Table 2, Fig. 5).

The comparison of the diversity curve (showing the number of species per unit) with the data on the appearance and disappearance of species shows that the most intensive origination of chitinozoan taxa took place, analogously to the acritarchs, at the beginning of the Ordovician (Arenig, Llanvirn) and at the end of the Caradoc, when the number of short-ranging species was relatively large. Origination intensified slightly also at the end of Pirgu time, but most of the Caradoc and Ashgill were characterized by a low appearance rate (Table 2, Fig. 5). The total rate of appearance (Table 3, Fig. 4) confirms the above statements, but shows additionally a relatively high rate during Kukruse-Idavere times and in early Nabala time, but also stresses the minimums in the Llandeilo (Uhaku time) and "middle" Caradoc (Jõhvi-Keila times).

The small origination event in Oandu time (Figs. 4, 5) is associated with a very low number of species. Therefore, the appearance of only four additional species has a considerable impact. Actually, this interval represents the minimum diversity level of chitinozoan assemblages, caused mostly by a substantial extinction event in the latest Keila time when $63 \%$ of the species disappeared. 


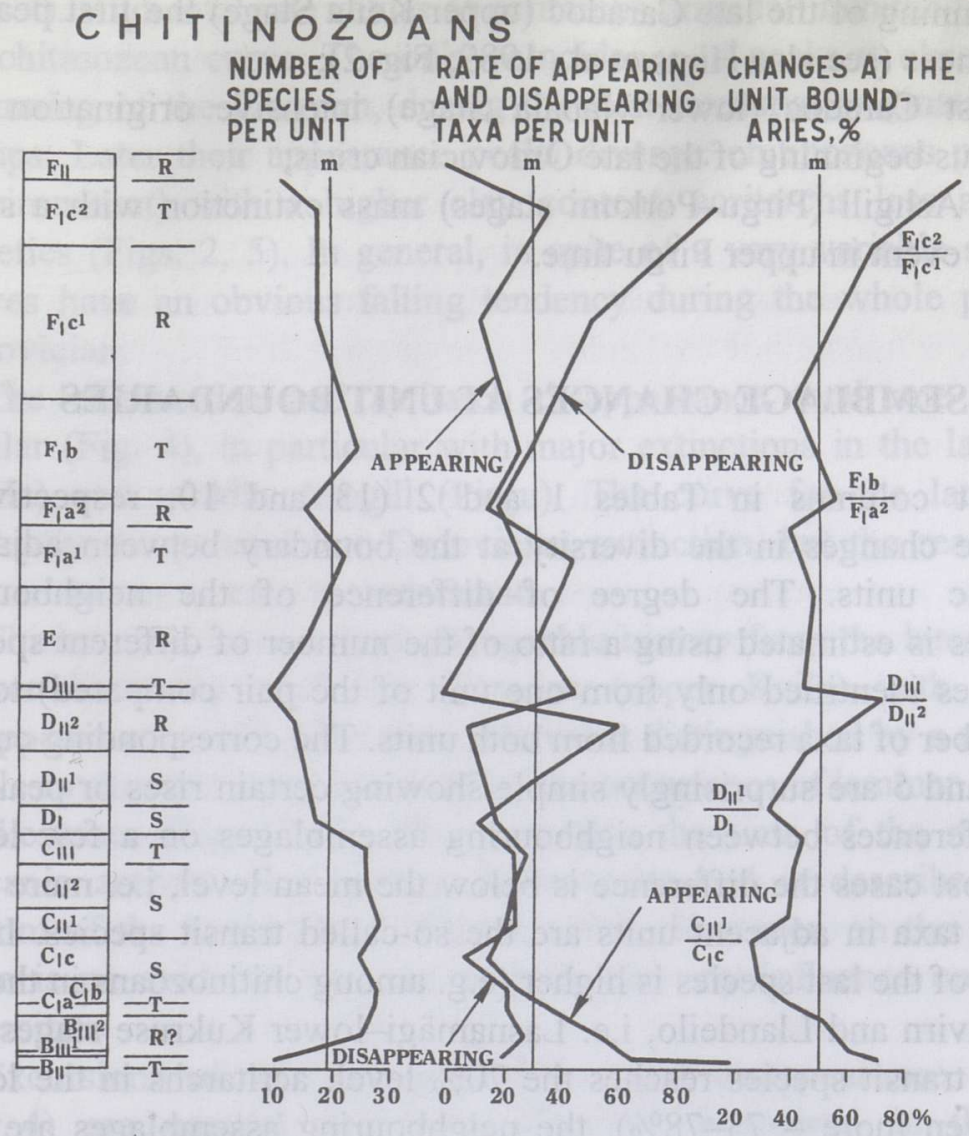

Fig. 5. Chitinozoan diversity. Explanations see Figs. 2 and 3. Numerical data in Table 2. R, S, T, intervals with a prevailing tendency in environmental evolution: $\mathrm{R}$, shallower water rocks, conventionally regression; $\mathrm{T}$, more argillaceous rocks, deepening or conventionally transgression; $\mathrm{S}$, without clear general tendency.

Earlier (from Kunda to lower Keila times) the disappearance rate (Fig. 5) was at the average level. After the low stand during Oandu time it began to increase, reaching the average level in Nabala time and the maximum level at the end of the Ordovician (in the upper Pirgu Stage). The total rate of disappearances (Fig. 4) varies more, but in general it resembles the disappearance curve (Fig. 5). As in the latter, there is a prominent peak in lower Kukruse time and a second one in Idavere time, possibly related to the extinction of a specific but short-term assemblage in the kukersite-bearing beds. Thus, with regard to the chitinozoans, the following main changes in the diversity of the assemblages can be distinguished:

(1) early Llanvirn (Kunda Stage) maximum of radiation;

(2) latest Llandeilo-early Caradoc (Kukruse-Idavere stages) interval of rapid diversity fluctuations; 
(3) beginning of the late Caradoc (upper Keila Stage) the first peak of disappearences (see also Hints et al., 1989; Fig. 2);

(4) latest Caradoc (lower Nabala Stage) intensive origination and simultaneous beginning of the late Ordovician crisis;

(5) late Ashgill (Pirgu-Porkuni stages) mass extinction with a small origination event in upper Pirgu time.

\section{ASSEMBLAGE CHANGES AT UNIT BOUNDARIES}

The last columns in Tables 1 and 2 (13 and 10 , respectively) characterize changes in the diversity at the boundary between adjacent stratigraphic units. The degree of difference of the neighbouring assemblages is estimated using a ratio of the number of different species (i.e. the ones identified only from one unit of the pair compared) to the whole number of taxa recorded from both units. The corresponding curves in Figs. 3 and 5 are surprisingly simple showing certain rises or peaks of greater differences between neighbouring assemblages on a few levels only. In most cases the difference is below the mean level, i.e. more than half of the taxa in adjacent units are the so-called transit species. If the percentage of the last species is higher (e.g. among chitinozoans in the top of the Llanvirn and Llandeilo, i.e. Lasnamägi-lower Kukruse stages, the rate of the transit species reaches the $70 \%$ level, acritarchs in the lower Caradoc even more $-73-78 \%$ ), the neighbouring assemblages are less different.

The greatest differences involve the acritarch assemblages at the beginning of the late Caradoc, at the lower boundary of the Ashgill, and in the late Ashgill. All the other assemblages are poorly distinguished, except that of the Oandu Stage (Figs. 3, 5), as very considerable changes in the chitinozoan and acritarch diversity take place on the lower and upper boundaries of this stage. The distinctiveness of the earliest and latest Ordovician assemblages evidently results from the early Ordovician evolutionary radiation and the late Ordovician mass extinction. The late Caradoc change could be related to a facies change. On the other hand, a small number of abrupt changes of assemblages at the boundaries of stratigraphic units indicates that the Rapla section, despite a large number of discontinuity surfaces, is relatively complete or there are evidently only a few substantial hiatuses in the sequence.

\section{DISCUSSION}

The comparison of the total rate of appearance curves by acritarchs and chitinozoans displays a surprising strict regular alternation of their peaks 
(Fig. 4). High total rate values of acritarchs often fall into the low stand of the chitinozoan curve. The only coincidence of peaks is observed at the beginning of the Llanvirn, during the first intensive origination of both groups. Later their appearance peaks diverge: chitinozoans prefer rocks (environment) with a higher clay content, acritarchs less argillaceous varieties (Figs. 2, 5). In general, in spite of a very variable shape, both curves have an obvious falling tendency during the whole post-Arenig Ordovician.

The chitinozoan and acritarch disappearance total rate curves are similar (Fig. 4), in particular with major extinctions in the late Caradoc (Keila) and middle Ashgill (Pirgu). The curve for the latter reflects evidently the general late Ordovician extinction, but the reasons of the former are not so easy to understand.

Chitinozoans have a very changeable history from the latest Llandeilo (lower Kukruse) until late Caradoc (upper Keila) with three high disappearance peaks. This time interval is distinguished by a more or less stable environment characterized by the occurrence of laminar and nodular wackestones (Figs. 2, 5). This was also the time of the most intense volcanic activity: the thickest $\mathrm{K}$-bentonite bed is described from the bottom of the Keila Stage (Põlma, 1972). However, on the other hand, there is no evidence that the ashbeds had any influence on the faunal diversity.

Excursions of the total appearance and disappearance rate curves (Fig. 4) are parallel and especially well expressed in the case of chitinozoans. Accordingly, one reason for disappearance peaks was a higher rate of occurring taxa. The same might be concluded from the parallel rise of the disappearance rates of both groups during the ArenigLlanvirn due to rapid origination and diversity rise. This does not mean that environmental aspects of the origination-extinction processes should be ignored, but it does indicate that these are not the only causes and in different intervals some other factors may dominate.

The late Keila extinction and diversity minimum in the Oandu time, profound assemblage changes on the boundaries of the latter unit coinciding with a considerable sedimentological change in the section evidence more about environmental influence in the biotic process. However, our data are insufficient for evaluating the significance of these events, but the data presented by Sepkoski (1995) confirm that the late Keila bioevent has not only a local but also much wider importance.

\section{CONCLUSIONS}

(1) The comparison of the diversity dynamics in the acritarch flora and chitinozoan fauna (?) in an Ordovician section of northern Estonia shows a 
significant correlation in the pattern of the most general processes represented by coinciding Arenig-Llanvirn radiation-origination events and mass extinctions at the end of the Ordovician.

(2) Both groups have in the late Caradoc (Oandu time) a very shortterm episode (about $1 \mathrm{Ma}$ ) that might be called the Oandu crisis. It is characterized by an extreme diversity low, distinct changes in the composition of the microfossil assemblages on its boundaries, and is preceded by a remarkable extinction event at the end of Keila time. This event seems to be caused by environmental agents and is globally observable.

(3) The fluctuation of different curves concurrently with some lithological features (clay content, relations of mud-grain-skeletal particles, etc.) do not explain unambigously the diversity dynamics, especially because the correlation is not consistent with the parallel total appearance and disappearance rate curves. Therefore a higher diversity of a group seems to be one cause for a higher extinction rate.

(4) The terminal Ordovician mass extinction began in both groups earlier than might be expected according to the short-term glaciation event proposed by Brenchley et al. (1994).

(5) The general pattern of microfossil diversity in the Rapla core is the same as established by Sepkoski (1995) for different groups of invertebrates: late Arenig-Llanvirn diversity rise and, with a maximum in the early-middle Caradoc (chitinozoans had a peak earlier), followed by a late Caradoc drop of diversity and a terminal Ordovician mass extinction.

(6) The latter conclusion advocates that general tendencies of biotic diversity might be observed also in only one good section if analysed adequately.

\section{ACKNOWLEDGEMENTS}

The authors are glad to thank Valdar Jaanusson for the critical reading of an early version of the MS and many useful suggestions. J. D. Cooper is thanked for editorial improvements and Paul Pärkma for technical help. The study was partly supported by the International Science Foundation (grant No. LKW100) and the Estonian Science Foundation (grant No. 314). This is a contribution to the IGCP project No. 335.

\section{REFERENCES}

Brenchley, P. J., Marshall, J. D., Carden, G. H. F., Robertson, D. B. R., Long, D. G. F., Meidla, T., Hints, L. \& Anderson, F. F. 1994. Bathymetric and isotopic evidence for a short-lived Late Ordovician glaciation in a greenhouse period. Geology, 22, 295-298. 
Jaanusson, V. 1976. Faunal dynamics in the Middle Ordovician (Viruan) of Baltoscandia. In The Ordovician System. Proc. Palaeontol. Assoc. Symposium Birmingham, 1974, Cardiff (Bassett, M. G., ed.). Univ. of Wales Press, 301-326.

Johnson, C. C. \& Kauffman, E. G. 1990. Originations, radiations and extinctions during the Cenomanian and Maastrichtian stages of the Cretaceous. In Extinction Events in Earth History (Kauffman, E. G. \& Walliser, O. H., eds.). Lecture Notes in Earth Sciences, 30, 305-324.

Hints, L., Meidla, T., Nõlvak, J. \& Sarv, L. 1989. Some specific features of the Late Ordovician evolution in the Baltic Basin. Proc. Acad. Sci. Estonian SSR. Geology, 38, 2, 83-87.

Kaljo, D., Nõlvak, J. \& Uutela, A. 1995. Ordovician microfossil diversity patterns in the Rapla section, Northern Estonia. In Ordovician Odyssey: Short Papers for the Seventh International Symposium on the Ordovician System. Las Vegas, Nevada, USA (Cooper, J. D., Droser, M. L. \& Finney, S. C., eds.). SEPM, Fullerton, California. Book $77,415-418$.

Männil, R. 1990. The Ordovician of Estonia. In Field Meeting Estonia 1990. An Excursion Guidebook (Kaljo, D. \& Nestor, H., eds.). Inst. Geol. Estonian Acad. Sci., Tallinn, 11-20.

Nestor, H. 1990. Some aspects of lithology of the Ordovician and Silurian rocks. In Field Meeting Estonia 1990. An Excursion Guidebook (Kaljo, D. \& Nestor, H., eds.). Inst. Geol. Estonian Acad. Sci., Tallinn, 27-32.

Põlma, L. 1972. Skeletal debris content and composition in the sediments of the northern facial belt of the East Baltic Ordovician (Rapla boring). Eesti NSV Teaduste Akadeemia Toimetised. Keemia, Geoloogia, 21, 4, 326-332 (in Russian).

Sepkoski, J .J., Jr. 1995. The Ordovician radiations: Diversification and extinction shown by global genus-level taxonomic data. In Ordovician Odyssey: Short Papers for the Seventh International Symposium on the Ordovician System. Las Vegas, Nevada, USA (Cooper, J. D., Droser, M. L. \& Finney, S. C., eds.). SEPM, Fullerton, California. Book 77, 393-396.

Tucker, R. D., Krogh, T. E., Ross, J. R. \& Williams, S. H. 1990. Time-scale calibration by highprecision $\mathrm{U}-\mathrm{Pb}$ zircon dating of interstratified volcanic ashes in the Ordovician and lower Silurian stratotypes of Britain. Letters. Earth and Planet. Sci., 100, 51-58.

Uutela, A. \& Tynni, R. 1991. Ordovician acritarchs from the Rapla borehole, Estonia. Bull. Geol. Surv. Finland, 353, 135.

Walliser, O. H. (ed.). 1986. Global Bio-Events. A Critical Approach. Lecture Notes in Earth Sciences, 8.

\title{
LISAND RAPLA PUURSÜDAMIKU ORDOVIITSIUMI MIKROFOSSIILIDE MITMEKESISUSE UURIMISELE
}

\author{
Dimitri KALJO, Jaak NÕLVAK, Anneli UUTELA
}

On uuritud akritarhide ja kitiinikute (Chitinozoa) mitmekesisuse muutumist Volhovi lademest kuni Porkuni lademeni. Selgus, et mõlemad rühmad tegid läbi kiire radiatsiooni Arenigis ja Llanvirnis. Hiliskaradokis Keila ea lõpul toimus esimene suurem väljasuremine (mitmekesisuse miinimum Oandu lademes) ning ordoviitsiumi lõpul (Pirgu ja Porkuni eal) massiline väljasuremine. See üldskeem on sarnane J. Sepkoski (1995) kirjeldatud selgrootute mitmekesisuse muutumise seaduspärasusega. 


\title{
ДОПОЛНЕНИЯ К ИЗУЧЕНИЮ ТАКСОНОМИЧЕСКОГО РАЗНООБРАЗИЯ ОРДОВИКСКИХ МИКРОФОССИЛИЙ ИЗ СКВАЖИНЫ РАПЛА, СЕВЕРНАЯ ЭСТОНИЯ
}

\author{
Димитри КАЛЬО, Яак НЫЛВАК, Аннели УУТЕЛА
}

Изучены акритархи и хитинозои из скв. Рапла, вскрывшей ордовикские отложения от верхов аренига до верхов ашгилла. Проанализировано количество таксонов в стратоне, скорость появления и исчезновения таксонов в стратоне за миллион лет, а также таксономические изменения на границах стратонов. Обе группы подверглись сильной радиации в арениге-лланвирне, первое их существенное вымирание произошло в позднем карадоке и уже массовое вымирание - в конце ордовика (пиргуское-поркуниское время). Остальные мелкие изменения, видимо, контролировались фациальными условиями. Общая схема изменений таксономического разнообразия микрофоссилий сходна с закономерностью, установленной Дж. Сепкоски (1995) для некоторых групп беспозвоночных. 